\title{
Characteristics of the Ejaculates from Meishan Boars at Various Ages
}

\author{
Hiroshi HaRAyama and Seishiro Kato* \\ Graduate School of Science and Technology, Kobe Unversity, \\ Nada-ku, Kobe-shi 657 \\ * Faculty of Agriculture, Kobe University, \\ Nada-ku, Kobe shi 657
}

(Received August 31, 1992)

\begin{abstract}
The age at which ejaculatory ability is achieved and age-related changes in the characteristics of ejaculates were examined in Meishan boars. All of the 12 boars examined showed detachment of the penis from the prepuce by 64 days of age. The first ejaculate could be collected at 73 to 78 days of age. The volume of the liquid portion, the weight of the gelatinous material, the total number of spermatozoa per ejaculate and the sperm concentration increased significantly untıl 11, 10,9 and 5 months of age, respectively. Percentages of progressively motile spermatozoa and morphologically abnormal spermatozoa in the ejaculates altered greatly until 3 months of age, and thereafter stayed at a good level. Percentages of live spermatozoa with normal acrosomes after storage at $4^{\circ} \mathrm{C}$ for 5 and 10 days were higher in ejaculates collected from boars older than 9 months, and percentages of progressively motile spermatozoa and hive spermatozoa with normal acrosomes after freeze-thawing in boars older than 8 months. These results suggest that Meishan boars acquire ejaculatory ability at approximately 2 months of age, but should not be used in service untıl later ages. It is also suggested and that ejaculates from boars younger than 9 months are less suitable for storage at $4^{\circ} \mathrm{C}$ $-196^{\circ} \mathrm{C}$
\end{abstract}

Anim. Sct. Technol. (Jpn.) 64 (4): 333-339, 1993

Key words : Meishan boar, semen, sexual maturity

Meishan pigs are noted for their early puber$\mathrm{ty}^{1,18,24)}$. We $\mathrm{e}^{6-8)}$ have reported that the rapid development of the reproductive organs of Meishan boars occurred after 45 days of age. Spermatozoa first appear in the rete testicular and epididymal fluids at approximately 75 days of age $e^{6,7,9)}$. The ability of the testis to produce morphologically normal spermatozoa and that of the epididymis to mature spermatozoa are established by 120 days of age $e^{6,9)}$. The secretory activity of the seminal vesicle, prostate and bulbourethral gland becomes active after about 2, 2 and 1 months of age, respectively ${ }^{8}$. To our knowledge, however, no detailed study on ejaculatory ability and age-related changes in the characteristics of ejaculates in Meishan boars has been reported. The objectives of the present study were to determine the age at which boars acquire ejaculatory ability and to characterize the ejaculates collected from the same boars at various ages.

\section{Materials and Methods}

Animals: A total of 15 Meishan boars were used. They were housed under the same conditions as previously described ${ }^{18)}$, except that the formula feed for the breeder (Nihon Nosan Kogyo Co., Yokohama, Japan) was 
given after 81 days of age.

Examination of the detachment of the penis from the prepuce: Twelve boars were given a sedative containing $20-40 \mathrm{mg}$ of $4^{\prime}$-fluoro-4[4-(2-pyridyl)-1-piperazinyl] butyrophenone (Stresnil, Sankyo Co., Tokyo, Japan) per head by an intramuscular injection every 5 days. The boar whose penis appeared out of the preputial orifice after injection was counted as an animal with the penis detached from the prepuce.

Collection of ejaculates and examination of their characteristics: Two groups of 3 boars each were used. In Group A, boars were trained to mount a small-sized dummy at less than 70 days of age. In Group B, training started at 120 days of age. After the first successful collection, semen was collected manually every 2 weeks by a single technician. At the semen collection, gelatinous material was separated from the liquid portion by filtration through double gauze. The volume of the liquid portion, the weight of gelatinous material, $\mathrm{pH}$, and the sperm concentration, motility and morphology were examined in each ejaculate within $90 \mathrm{~min}$ after collection. Sperm concentration was determined using a haemocytometer, and the total number of spermatozoa per ejaculate was calculated by multiplication of sperm concentration and volume of the liquid portion. The spermatozoa were evaluated for their motility and morphology according to the procedures described previously ${ }^{(6)}$. In brief, motility estimates were made in a small drop of semen under a cover slide using a bright-field microscope equipped with a heated stage $\left(37^{\circ} \mathrm{C}\right)$. An aliquot of semen was fixed with an equal volume of 0.25 \% (V/V) glutaraldehyde in phosphate-buffered saline, smeared on a glass slide, and stained in a phosphate-buffered solution of Giemsa stain (Merck, Darmstadt, Germany). Approximately 200 spermatozoa were counted at random by light microscopy to determine the percentage of morphologically abnormal spermatozoa.
Storage of semen at $4^{\circ} \mathrm{C}$ and $-196^{\circ} \mathrm{C}$ : TCG solution ${ }^{14)}$, composed of Tris (hydroxymethyl)aminomethane $(1.21 \mathrm{~g} / 90 \mathrm{ml})$, citric acid $(0.60$ $\mathrm{g} / 90 \mathrm{ml})$, glucose $(3.00 \mathrm{~g} / 90 \mathrm{~m} l)$ and penicillin $(90,000$ I.U. $/ 90 \mathrm{ml})$, was used as a basic diluent. The semen collected from Group B was centrifuged for $10 \mathrm{~min}$ at $500 \times \mathrm{g}$ and the resulting sperm pellets were resuspended in TCG solution containing egg yolk $(10 \% \mathrm{~V} / \mathrm{V})$ and catalase $(15,000$ Sigma units $/ 100 \mathrm{~m} l$, Sigma Chemical Co., St. Louis, USA) to give a concentration of approximately $2 \times 10^{8}$ cells $/ \mathrm{m} l$. Sperm suspensions were cooled to $4^{\circ} \mathrm{C}$ over $4 \mathrm{~h}$ and stored for 5 or 10 days. In the case of freezing spermatozoa, sperm pellets obtained after centrifugation were resuspended in TCG solution containing egg yolk $(20 \% \mathrm{~V} / \mathrm{V})$ to give a concentration of approximately $4 \times 10^{8} \mathrm{cells} / \mathrm{ml}$, and then frozen into pellets of $0.2 \mathrm{ml}$ on the surface of dried ice ${ }^{19)}$ following an additional dilution with an equal volume of the abovementioned diluent containing glycerol ( $2 \%$ $\mathrm{V} / \mathrm{V})^{5}$, After being stored in liquid nitrogen for more than 2 days, 2 frozen pellets were thawed in $1 \mathrm{~m} l$ of Beltsville thawing solution prewarmed at $40^{\circ} \mathrm{C}^{22}$.

A portion of the $4^{\circ} \mathrm{C}$-stored or frozen-thawed sample was shaken at $37^{\circ} \mathrm{C}$ for 15,30 and 60 min, after which the percentages of progressively motile spermatozoa were estimated and the maximum percentage was recorded. To determine the percentage of live spermatozoa with normal acrosomes, the remaining sample was diluted with an equal volume of TCG solution containing 1\% trypan blue, incubated at $37^{\circ} \mathrm{C}$ for $15 \mathrm{~min}$, smeared on glass slides and air-dried. The slides were rinsed in water, blotted and fixed in Orth solution at room temperature for $45 \mathrm{~min}$. After fixation, they were rinsed in water, blotted and stained in buffered Giemsa solution at room temperature for $90 \mathrm{~min}$. The stained smears were rinsed in water, air-dried and mounted. Approximately 200 spermatozoa for each preparation were counted at random with light microscope at 
$1000 \times$.

Analysis of results: Data were analyzed using Duncan's multiple range test ${ }^{23)}$.

\section{Results}

In 2 of the boars examined, detachment of the penis from the prepuce was found as early as 45 to 49 days of age and in the rests by 64 days. The average age of detachment was 57 days.

The first ejaculate could be collected from boars of Group A at 73 to 78 days of age. Observations of the appearance of semen during ejaculation revealed that the semen from Group A was much less opaque throughout the whole ejaculatory process, although opaqueness of the semen increased with the passage of age. The semen collected from Group B was more opaque than that from Group A. However,
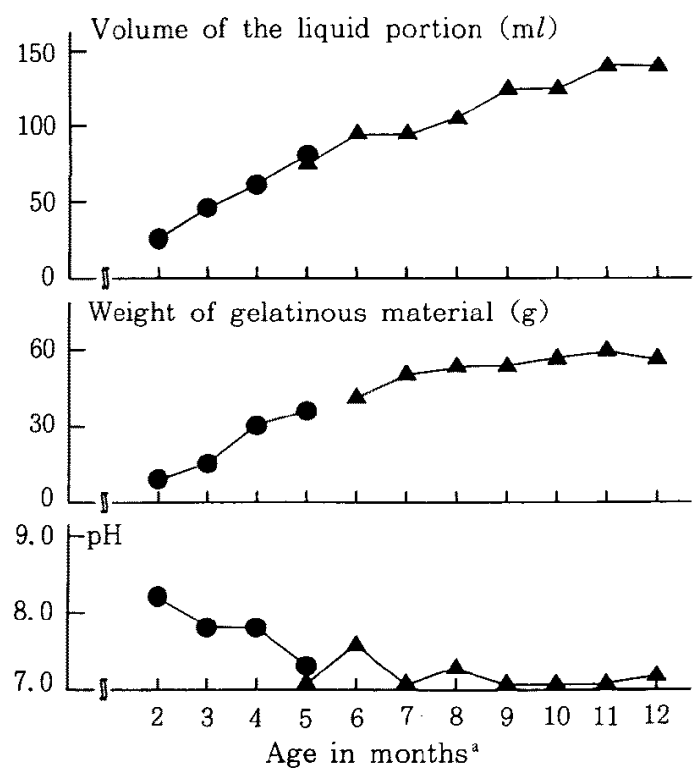

Fig. 1. Volume of the liquid portion, weight of gelatinous material and $\mathrm{pH}$ of the ejaculate collected from Meishan boars at various ages in Group $A(-)$ and $B(\boldsymbol{A})$. Values are means of 5-7 ejaculates. " $n$ " months of age indicates a period between " $30 \times \mathrm{n}$ " and " $30 \times(\mathrm{n}+1)-$ 1 " days of age. the sperm-rich fraction was not clearly distinguished from the sperm-poor fraction until 7 months of age.

As shown in Fig. 1, at 2 months of age, the volume of the liquid portion and the weight of gelatinous material were $23 \mathrm{ml}$ and $9 \mathrm{~g}$, respectively, and thereafter increased significantly until 11 and 10 months, respectively. The $\mathrm{pH}$ value of the ejaculates gradually declined until 7 months of age, followed by only minor fluctuations.

As shown in Fig. 2, although the total number of spermatozoa per ejaculate varied between individuals, it increased slowly from 2 $\left(6.5 \times 10^{6}\right.$ to $3.4 \times 10^{9}$ cells) to 4 months of age
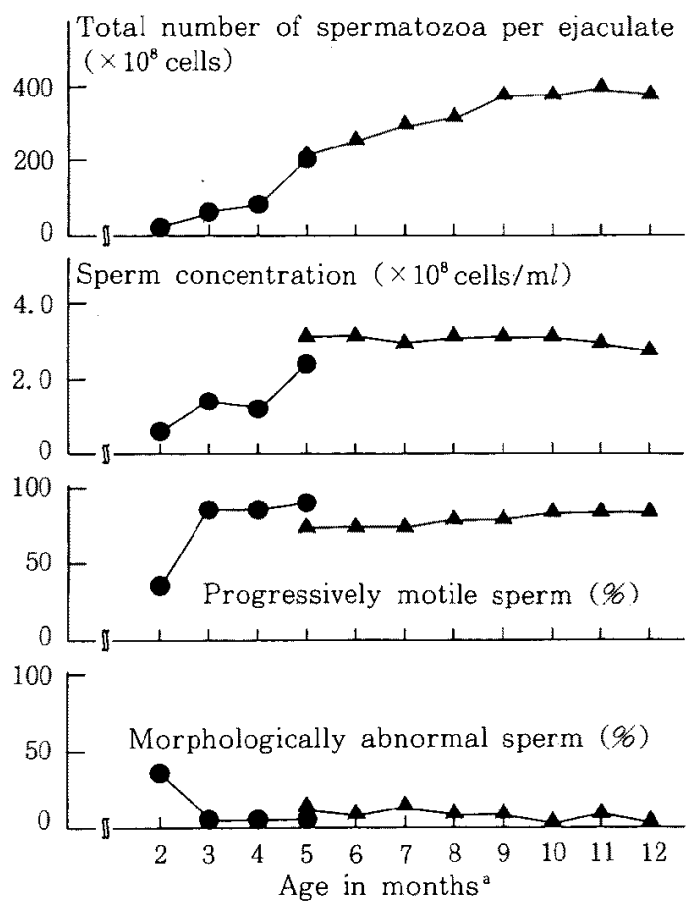

Fig. 2. Total number of spermatozoa, sperm concentration, and percentages of progressively motile spermatozoa and of morphologically abnormal spermatozoa in ejaculates collected from Meishan boars at various ages in Group $\mathrm{A}(\boldsymbol{\bullet})$ and $\mathrm{B}(\mathbf{A})$. Values are means of 5-7 ejaculates.

${ }^{\mathrm{a}}$ See footnote in Fig. 1. 
HARAYAMA and KaTO

Table 1. $\quad 4^{\circ} \mathrm{C}$-storage of spermatozoa ejaculated from Meishan boars (Group B) at various ages

\begin{tabular}{|c|c|c|c|c|c|}
\hline \multirow[b]{3}{*}{$\begin{array}{l}\text { Age in } \\
\text { months }\end{array}$} & \multirow[b]{3}{*}{$\begin{array}{l}\text { No. of } \\
\text { ejaculates } \\
\text { examined }\end{array}$} & \multicolumn{4}{|c|}{ At $4^{\circ} \mathrm{C}$ for } \\
\hline & & \multicolumn{2}{|c|}{5 days } & \multicolumn{2}{|c|}{10 days } \\
\hline & & $\begin{array}{l}\text { Progressively } \\
\text { motile sperm } \\
\qquad(\mathscr{6})\end{array}$ & $\begin{array}{l}\text { Live sperm } \\
\text { with normal } \\
\text { acrosomes }(\%)\end{array}$ & $\begin{array}{c}\text { Progressively } \\
\text { motile sperm } \\
\text { (\%) }\end{array}$ & $\begin{array}{l}\text { Live sperm } \\
\text { with normal } \\
\text { acrosomes }(\mathscr{b})\end{array}$ \\
\hline 5 & 4 & $64 \pm 8$ & $35 \pm 3^{d}$ & $43 \pm 5$ & $23 \pm 3^{c}$ \\
\hline 6 & 5 & $73 \pm 6$ & $41 \pm 5^{\mathrm{cd}}$ & $55 \pm 2$ & $22 \pm 2^{c}$ \\
\hline 7 & 6 & $72 \pm 5$ & $42 \pm 3^{c d}$ & $62 \pm 3$ & $20 \pm 4^{c}$ \\
\hline 8 & 3 & $78 \pm 4$ & $51 \pm 6^{\mathrm{bcd}}$ & $43+9$ & $20 \pm 2^{c}$ \\
\hline 9 & 3 & $77 \pm 3$ & $61 \pm 3^{b}$ & $60 \pm 8$ & $43 \pm 4^{b}$ \\
\hline 10 & 6 & $79 \pm 2$ & $58 \pm 4^{b c}$ & $58 \pm 4$ & $38 \pm 4^{b}$ \\
\hline 11 & 5 & $72 \pm 4$ & $56 \pm 2^{b c}$ & $48 \pm 4$ & $38 \pm 3^{b}$ \\
\hline
\end{tabular}

Values are means \pm SEM.

a See footnote in Fig. 1.

${ }^{\text {bcd }}$ Values within the same colume with different superscript letters differ significantly, $P<0.05$.

$\left(2.4 \times 10^{9}\right.$ to $1.5 \times 10^{10}$ cells $)$ and then rapidly until 5 months ( 1.1 to $3.1 \times 10^{10}$ cells). After 5 months of age, it showed a steady but slow increase until 9 months $\left(2.1\right.$ to $4.4 \times 10^{10}$ cells $)$. The increase in the sperm concentration occurred until 5 months of age, followed by no significant changes. The percentage of progressively motile spermatozoa was $35 \%$ at 2 months of age, and then it increased rapidly to $83 \%$ at 3 months. Morphologically abnormal spermatozoa, which were mainly abnormal heads, were contained at a high level $(33 \%)$ in the ejaculates collected at 2 months of age. At 3 months of age, however, the percentage reduced to $7 \%$, and thereafter stayed between 3 and $12 \%$.

As shown in Table 1, the percentage of progressively motile spermatozoa after $4^{\circ} \mathrm{C}$ storage was not significantly affected by the age of the boars at semen collection. However, the percentages of live spermatozoa with normal acrosomes after storage for 5 and 10 days were significantly higher in samples collected at more than 9 months of age.

As shown in Table 2, the percentages of progressively motile spermatozoa and of live spermatozoa with normal acrosomes after frozen storage were higher in samples collected at
Table 2. Frozen storage of spermatozoa ejaculated from Meishan boars (Group B) at various ages

\begin{tabular}{cccc}
\hline \hline $\begin{array}{c}\text { Age in } \\
\text { months }\end{array}$ & $\begin{array}{l}\text { No. of } \\
\text { ejaculates } \\
\text { examined }\end{array}$ & $\begin{array}{c}\text { Progressively } \\
\text { motile sperm } \\
(\%)\end{array}$ & $\begin{array}{l}\text { Live sperm } \\
\text { with normal } \\
\text { acrosomes }(\%)\end{array}$ \\
\hline 7 & 3 & $25 \pm 9^{\mathrm{c}}$ & $16 \pm 0^{\mathrm{c}}$ \\
8 & 3 & $47 \pm 3^{\mathrm{b}}$ & $36 \pm 2^{\mathrm{b}}$ \\
9 & 3 & $50 \pm 3^{\mathrm{b}}$ & $40 \pm 1^{\mathrm{b}}$ \\
$10-11$ & 4 & $50 \pm 3^{\mathrm{b}}$ & $38 \pm 2^{\mathrm{b}}$ \\
\hline
\end{tabular}

Values are means $\pm S E M$.

a See footnote in Fig. 1.

bc Values within the same colume with different superscript letters differ significantly, $\mathrm{P}<0.05$.

more than 8 months of age.

\section{Discussion}

In all of the boars examined, the penis was detached from the prepuce by 64 days of age. The first ejaculate could be collected from boars of Group A at 73 to 78 days of age. These results suggest that Meishan boars acquire ejaculatory ability soon after their penis is freed from the prepuce, at approximately 2 months of age. According to previous studies on boars of Yorkshire ${ }^{4,10)}$, Berkshire ${ }^{20)}$, Large White ${ }^{21)}$, Poland China ${ }^{21)}$, Duroc ${ }^{4)}$, crossbred Yorkshire-Duroc-Hampshire ${ }^{17)}$ and cross- 


\section{Characteristics of Ejaculates from Meishan Boars}

bred Yorkshire-Hampshire--Duroc breeds ${ }^{2)}$, penile detachment from the prepuce and first collection of ejaculates occur at 4 to 5 and 5 to 6 months, respectively, which are remarkably later than those in Meishan boars.

The volume of the liquid portion of the ejaculates and the weight of gelatinous material increased significantly until 11 and 10 months of age, respectively. This indicates that the secretory activity of the accessory genital glands is enhanced with the passage of age. Indeed, the seminal vesicle continues to grow until 7 to 11 months of age ${ }^{8)}$.

Ito et al. ${ }^{11)}$ reported that fresh semen containing more than $4.0 \times 10^{9}$ cells was necessary to achieve reasonable fertility for artificial insemination. According to Johnson et al. ${ }^{12.13}$, when diluted semen containing $3.0 \times 10^{9}$ spermatozoa were inseminated into sows on the same day of the collection, farrowing rates, total number of piglets and number of live piglets per litter obtained were satisfactory. Based on these reports, it is necessary to inseminate at least $3.0 \times 10^{9}$ spermatozoa into the female for the purpose of high fertility and large litter size. In the present study, the total number of spermatozoa per ejaculate did not constantly exceed $3.0 \times 10^{9}$ cells until 5 months of age, although sperm motility and morphology reached a definitive level as early as 3 months. We have reported that the weight of the testis and epididymis and the diameter of the seminiferous tubules increased rapidly until 5 to 6 months of age $e^{6,7)}$. These findings suggest that Meishan boars should not be used in service until after 6 months of age. In fact, Meishan boars begin to be used at 6 to 8 months of age in breeding farms in China ${ }^{3.24}$, where most of the services are performed by means of artificial insemination using diluted whole semen on the same day of collection or after short-term storage for less than 2 days at 13 to $20^{\circ} \mathrm{C}^{15)}$. However, the results obtained in this study suggest that when relatively long-term storage of diluted semen at $4^{\circ} \mathrm{C}$ or frozen storage is needed, boars older than 9 months should be used as donors.

\section{Acknowledgement}

We thank Daiei, Inc., for the financial support.

\section{References}

1) Bazer, F.W., W.W. Thatcher, F. Martinat-Botte and M. Terqui, Sexual maturation and morphological development of the reproductive tract in Large White and prolific Chinese Meishan pigs. J. Reprod. Fert., 83 : 723-728. 1988.

2) Berger, T., J.P. MAHone, G.S. Svoboda, K.W. Metz and E.D. ClegG, Sexual maturation of boars and growth of swine exposed to extended photoperiod during decreasing natural photoperiod. J. Anim. Sci., 51 : 672-678. 1980.

3) Cheng, P., Pig breeds resources and their utilization in China. Jpn. J. Swine Sci., 27: 1-16. 1990.

4) Esbenshade, K.L., W.L. Singleton, E.D. ClegG and H.W. Jones, Effect of housing management on reproductive development and performance of young boars. J. Anim. Sci., 48 : 246-250. 1979.

5) Harayama, H., S. Kato, I. Nanjo, S. KANDA and T. TOKUMARU, Storage of Meishan pig spermatozoa. Jpn. J. Anim. Reprod. Technol., 10 : 10-14. 1988.

6) Harayama, H., I. NanJo, S. Kanda and S. Kato, Testicular development in Chinese Meishan boars. Theriogenology, 36 : 637644. 1991.

7) Harayama, H., I. Nanjo, S. Kanda and S. Kato, Development of the epididymis in Meishan boars. AJAS, 5 : 165-171. 1992.

8) Harayama, H., S. Kanda and S. Kato, Development of the accessory genital glands in Meishan boars. Anim. Sci. Technol. (Jpn.), 63: 1115-1122. 1992.

9) Harayama, H. and S. Kato, Changes in motility and morphology of spermatozoa during their transit through the epididymis in Meishan boars at various ages. Anim. Sci. Technol. (Jpn.), 63: 462-467. 1992.

10) ITo, S. and T. Niwa, Studies on the age of sexual maturity of the boar. I. On the Yorkshire Breed. Bull. Zootech. Exp. Sta., $53: 1-49.1946$. 
11) Ito. S., T. Niwa, A. Kubo and A. Mizuho, Studies on the artificial insemination in swine. Bull. Zootech. Exp. Sta., 55 : 1-74. 1948.

12) Johnson, L.A., J.G. AAlbers, C.M.T. WILLEMS and W. SYBESMA, Use of boar spermatozoa for artificial insemination. I. Fertilizing capacity of fresh and frozen spermatozoa in sows on 36 farms. J. Anim. Sci., 52 : 1130-1136. 1981.

13) Johnson, L.A. J.G. A.ALbERS, C.M.T. Whllems, J.H.M. RADEMAKER and C.E. RexRoAD, Jr., Use of boar spermatozoa for artificial insemination. III. Fecundity of boar spermatozoa stored in Beltsville liquid and Kiev extenders for three days at $18^{\circ} \mathrm{C}$. J. Anim. Sci., $54:$ 132-136. 1982.

14) Kato, S, A. Iritani and Y. Nishikawa, Study on composition of diluent for frozen storage of boar semen. Jpn. J. Zootech. Sci., 45: 58 (Abstr.). 1974.

15) Kato, S., Reproduction of Meishan pigs. in Studies on Native Pigs of China. I. A Field Survey on the Meishan Pig. (KandA, S. ed.) 21-25. Kobun-sha. Kobe. 1987.

16) Kato, S., T. YAsui and S. Kanda, Changes in motility and morphology of goat spermatozoa during their transit through the epididymis. Mem. Grad. School Sci. \& Technol., Kobe University., 5-B : 35-42. 1987.

17) Mahone, J.P., T. Berger, E.D. Clegg and W.L. Singleton, Photoinduction of puberty in boars during naturally occurring short day lengths. J. Anim. Sci., 48: 1159-1164. 1979.

18) Miyano, T., J. Akamatsu, S. Kato, I. NANJO and S. KANDA, Ovarian development in Meishan pigs. Theriogenology, $33: 769-775.1990$.

19) Nagase, $H$. and T. Niwa, Deep freezing bull semen in concentrated pellet form. Proc. Vth Int. Congr. Anim. Reprod. Trento, III : 410. 1964.

20) Nrwa, T. and A. Mizuho, Studies on the age of sexual maturity of the boar. II. On the Berkshire Breed. Bull. Natl. Inst. Agr. Sci. (Yahagi, Chiba, Japan) Series G (Animal Husbandry), 9 : 141-157, 1954.

21) Niwa, T. and A. Mrzuho, Studies on the age of sexual maturity of the boar. III. On the Large Whites and Poland Chinas. Bull. Natl. Inst. Agr. Sci. (Yahagi, Chiba, Japan) Series G (Animal Husbandry), 9: 161-177. 1954.

22) Pursel, V.G. and L.A. Johnson, Freezing of boar spermatozoa: fertilizing capacity with concentrated semen and a new thawing procedurc. J. Anim. Sci., 40: 99-102. 1975.

23) Steel, R.G.D. and J.H. Torrie, Principles and Procedures of Statistics. McGraw-Hill Book Co. New York. 1960.

24) WANG, R.X., Reproductive characteristics of the Fengjing pigs. in Proc. Chinese Pig Symposium, 6-16. EAAP. Toulouse, France. 1990. 


\title{
種々の月齢で採取した梅山豚精液の性状
}

\author{
原山 洋・加藤征史郎 ${ }^{*}$ \\ 神戸大学大学院自然科学研究科, 神戸市灘区 657 \\ * 神戸大学農学部, 神戸市灘区 657
}

\begin{abstract}
雄梅山豚における生殖機能の発達過程を明らかにする日的で, 射精能力の発達および月齢に伴う精淮

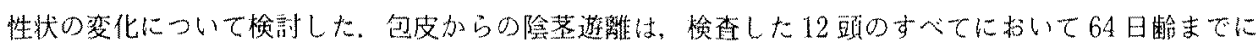

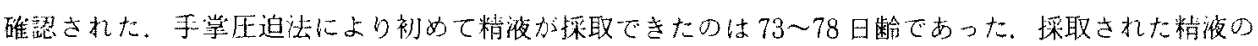
液体部量, 膠様物重量, 1 射精当りの総精子数抢よび精子濃度はそれぞれ11力月歯, 10 力月龄, 9 力

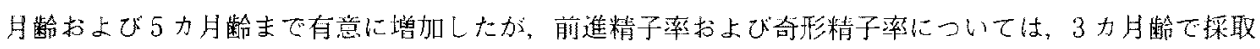
した精液で成豚の精液に匹敵する成綪加得られた。他力，5日間および 10 日間の $4{ }^{\circ} \mathrm{C}$ 保仔後の試料に おりる正常な頭帽を持つ生存精子の割合は，9 力月龄以上の雄加ら採取した精没老用いた場合に有意心 高く，また，凍結保仔後の試料での前進精子率扰よび正常な頭帽を持つ生存精子の割合は 8 力月齢以上

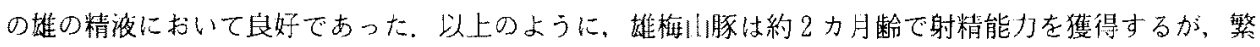

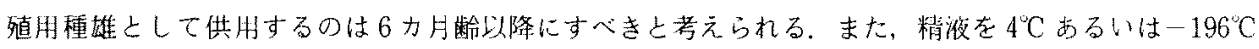

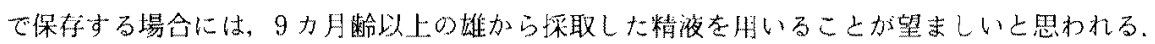

日畜会報，64(4)：333-339，1993 